\title{
O Pentesilei Heinricha von Kleista w przekładzie Witolda Hulewicza
}

DOI: http://dx.doi.org/10.12775/LC.2018.051

\begin{abstract}
Streszczenie: Przedmiotem artykułu jest refleksja nad polskim przekładem sztuki Heinricha von Kleista Pentesilea, dokonanym w latach trzydziestych XX wieku przez wybitnego thumacza literatury niemieckiej Witolda Hulewicza. Dramat opublikowany przez Kleista w roku 1808 - bardzo swobodnie nawiązujący do wątków antycznych i niezwykły pod względem stylistyki - budził z początku wiele kontrowersji. Popularność zdobył w XX wieku, a postać wewnętrznie rozdartej, nieokiełznanej królowej Amazonek szybko zyskała grono wielbicieli wśród niemieckich elit twórczych. Specyficzny język Kleista sprawia, że tekst sztuki stanowi ogromne wyzwanie dla thumacza. Omawiany w artykule przekład podzielił krytyków. Jest jednak bez wątpienia wielkim dokonaniem translatorskim i ostatnim opublikowanym tłumaczeniem Witolda Hulewicza, poety i patrioty rozstrzelanego przez Niemców w Palmirach w 1941 roku.
\end{abstract}

Słowa kluczowe: Witold Hulewicz, Heinrich von Kleist, Pentesilea, przekład, Środy Literackie

\section{On Heinrich von Kleist's Penthesilea in the Translation by Witold Hulewicz}

Abstract: This paper discusses the Polish edition of Heinrich von Kleist's drama Penthesilea, which
was translated in the 1930s by outstanding German literature translator Witold Hulewicz. The play,
published by Kleist in 1808, loosely referencing Antique themes and truly extraordinary in style, at
first generated serious controversy. It gained popularity in the 20th century, when the character of the
internally torn and unpredictable queen of the Amazons quickly attracted many fans among German

\footnotetext{
* Dr hab., germanistka, kierownik Katedry Filologii Germańskiej UMK w Toruniu. Jej zainteresowania skupiają się na niemieckiej literaturze XIX i XX wieku (Heinrich von Kleist, Robert Musil, Franz Kafka) i dotyczą narracji, recepcji twórczości wybranych autorów oraz badań porównawczych. E-mail: klentak@umk.pl.
} 
artistic elite. Kleist's peculiar use of language posed a great challenge to the translator. The translation discussed in the article divided the critics. Although accused of departing from the original, it is an outstanding intellectual achievement and the last translation published by Witold Hulewicz, a poet and patriot shot by the Germans in Palmiry in 1941.

Keywords: Witold Hulewicz, Heinrich von Kleist, Penthesilea, translation, Literary Wednesdays

\section{Witold Hulewicz - życie między frontami}

W ry jest dziś znany niewielu ${ }^{1}$ chociaż to postać niezwylka i fascynująca: pośrednik między kulturą polską a niemiecką i niezmordowany propagator literatury niemieckiej w Polsce, na którego całym życiu zaważyło właśnie owo znalezienie się „pomiędzy” - a raczej „zarówno - jak i”: w obszarze polskości i niemieckości - w sensie języka, kultury, zainteresowań i kompetencji, ale i politycznych konsekwencji takiego właśnie umiejscowienia. Życie tego nieprzeciętnie aktywnego człowieka - barwne i bogate - było wplątane niezależnie od czyjejkolwiek woli w czasy niespokojne i mało przyjazne, tak że gdy spojrzeć na nie jak na zamknięty już rozdział, przychodzi na myśl nie tyle obraz kładki, pomostu ponad granicami, co klinczu - nieuniknionego bolesnego zwarcia. Hulewicz - pseudonimy „Olwid” i „Grzegorz” (ten pierwszy zrodzony z młodzieńczej fantazji dla publikacji własnych wierszy i przekładów poezji w ekspresjonistycznym „Zdroju”, ten drugi na potrzeby konspiracji po kapitulacji Warszawy w 1939 roku) - urodzony 26 listopada 1895 w Kościankach koło Strzałkowa i Wrześni, a zamordowany 12 czerwca 1941 w Palmirach, przeżył niespełna 46 lat. Polskość i niemieckość splatały i zderzały się w tej biografii od początku do końca.

Ze strony ojca rodzinne korzenie, a z nimi świadomość własnej tradycji i tożsamości narodowej, zatem żywa pamięć Polski przedrozbiorowej, sięgają XIV wieku (HulewiczFeillowa 1988: 7). Rodzice Witolda - Leon i Helena - bardzo angażowali się w prace społecznikowskie w swoim środowisku oraz $\mathrm{w}$ patriotyczne wychowanie dzieci: na porządku dziennym było głośne czytanie literatury polskiej w domu i edukacja w zakresie zabronionych przedmiotów. Podział na „my” - Polacy i „oni” - niemieccy zaborcy był jasny i oczywisty ${ }^{2}$. Wszystkim dzieciom nadano polskie imiona, a o imię córki Katarzyny (a nie Kathariny) ojciec stoczył formalną batalię (ibid.: 50-51). W roku 1908 wobec uchwalenia

\footnotetext{
1 W stulecie urodzin Hulewicza Zarząd Oddziału Warszawskiego Związku Literatów Polskich i Oficyna Literatów i Dziennikarzy "Pod Wiatr” ustanowiły doroczną nagrodę jego imienia, przyznawaną podczas Warszawskiej Jesieni Poezji. Jednak środowisko pielęgnujące dziś pamięć Witolda Hulewicza to stosunkowo wąski krąg, po części osób ściśle związanych z Oficyną „Pod Wiatr”. Prezesem Stowarzyszenia jest Romuald Karaś, prywatnie ojciec Agnieszki Karaś, autorki najpełniejszego (obok wspomnieniowej książki Agnieszki HulewiczFeillowej, córki tłumacza - Rodem z Kościanek, Kraków 1988) i najnowszego opracowania biograficznego poświęconego Hulewiczowi (Miał zbudować wieżę, Warszawa 2003) oraz jego nieco okrojonej na potrzeby odbiorcy niemieckiego wersji Der Pole, der auch Deutscher war (Osnabrück 2004). Kai Westerman, autor i producent filmu dokumentalnego pod tym samym tytułem, jest jej mężem.

2 Decyzje życiowe i ekonomiczne, jak inwestycje w zakup ziemi, podejmowano nierzadko właśnie z pobudek patriotycznych, by „z rąk szwabskich wydrze[ć] szmat polskiej ziemi” (Hulewicz-Feillowa 1988: 54).
} 
przez parlament niemiecki „ustawy wywłaszczeniowej” Leon liczył się z realną koniecznością zbrojnej walki o swój majątek (Karaś 2003: 22) i uzyskał deklarację synów, że w razie takiej konieczności staną u jego boku.

Trzej starsi bracia Witolda Jerzy, Bohdan i Wacław należeli do nielegalnego kółka samokształceniowego Towarzystwa Tomasza Zana. Jerzy został zresztą relegowany ze szkoły z wilczym biletem za narysowanie na tablicy polskiego godła (Hulewicz-Feillowa 1988: 49). Edukacją Witolda - wobec istnienia przedmiotów oficjalnych i zakazanych - zajmowali się najpierw korepetytorzy i rodzice. $\mathrm{W}$ latach gimnazjalnych najmłodszy z braci także należał do skautingu i Towarzystwa Tomasza Zana. Warto uświadomić sobie cały ów klimat dzieciństwa Hulewicza wobec dramatu, jakim było dla niego wcielenie do armii niemieckiej i skierowanie na front francuski podczas I wojny światowej, gdzie pełnił funkcję sygnalisty. Jego przejmujące listy z frontu to świadectwo okropieństw Wielkiej Wojny spotęgowanych tragicznym przymusem walki w mundurze wroga (Karaś 2003: 27-34, 39-44). Kolejnym etapem w życiu dwudziestotrzyletniego Hulewicza, którego już od paru lat bardziej pociąga literatura i organiczna praca na rzecz kultury, jest jednak udział w powstaniu wielkopolskim, gdzie współorganizuje pierwszą kompanię łączności i otrzymuje stopień kapitana. W latach dwudziestych najistotniejszy epizod w jego życiorysie jako pośrednika między kulturami stanowi etap wileński: Hulewicz tworzy miejscowy oddział Związku Literatów Polskich, sprowadza do Wilna z Warszawy teatr-laboratorium Juliusza Osterwy, od podstaw buduje Rozgłośnię Wileńską Polskiego Radia. Ponadto w roku 1927 powołuje do życia oryginalną instytucję Śród Literackich, poświęconych m.in. promocji literatury i szerzej - kultury europejskiej, a w szczególności i niemieckiej ${ }^{3}$. Nowatorskie interkulturowe pomysły Hulewicza, a także energia, z jaką starał się je wcielać w życie, przysporzyły mu jednak wrogów. Gorzki paradoks stanowi to, że temu oddanemu polskim sprawom patriocie z Wielkopolski przyczepiono w Wilnie łatkę „krzyżaka” i germanizatora ${ }^{4}$.

W dorobku translatorskim Hulewicza Pentesilea jest ostatnim dziełem wydanym drukiem i stanowi niezamierzone zwieńczenie jego dokonań na tym polu.

\section{Penthesileia Witolda Hulewicza: praca nad przekładem}

Pracę nad tłumaczeniem Hulewicz rozpoczął w Wilnie. Całość ukazała się dopiero w 1938 we Lwowie, ale już w roku 1933 trzy czasopisma - „Droga”, „Gazeta Literacka” i „Kurier

3 Spotkania odbywały się w latach 1927-1935. Bohaterem pierwszego był duński badacz literatury skandynawskiej i niemieckiej Georg Brandes (Hulewicz z matką grali także utwory Beethovena). Środy literackie (poświęcone m.in. Beethovenowi i Rilkemu, ale także Remarque'owi, Kleistowi, Ferdynandowi Brucknerowi) prędko stają się znane poza Wilnem, w całej Polsce - przyjeżdżają tu Irena Solska, Stefan Jaracz, Maria Dąbrowska, Elga i Rudolf Kernowie czy takie sławy jak Karol Szymanowski i Gilbert Keith Chesterton. Zaproszony był też i Rainer Maria Rilke, z którym połączyła Hulewicza bliska znajomość. Gdyby nie stan zdrowia (Rilke zmarł w 1926 roku), zapewne i on odwiedziłby Wilno, por. AHF, 154-155.

4 Więcej o konflikcie Hulewicza ze środowiskiem skupionym wokół Stanisława Cata-Mackiewicza zob. Karaś 2003: 210-211, 219, 230. O życiu i działalności Hulewicza por. także Surynt 2017. 
Wileński” - zamieściły różne fragmenty tego przekładu (Meyer-Fraatz 2002: 209)5. Wydanie książkowe z roku 1938 jest bardzo staranne (różni się nieco od późniejszej edycji Ossolineum z roku 1969 przede wszystkim pisownią imion własnych: oprócz samej królowej Amazonek ${ }^{6}$ dotyczy to i innych postaci bądź nazw: Achlilleus - Achilles, Odysseus Odyseusz, Antilochos - Antilochus, Myrmidonów - Mirmidonów, Illion - Ilion). Lwowski tom zawiera uwagi tłumacza o tekście oryginału i dotychczasowych próbach inscenizacji oraz szczegółowy opis ilustracji z okładki (tzw. czerwonofigurowej czary Pentesilei). Znajdziemy w nim także obszerne posłowie Penthesileia, tragedia Henryka Kleista pióra Zygmunta Falkowskiego ${ }^{7}$. Falkowskiemu uczyniono wprawdzie później zarzut, że bardziej jest tu poetą niż badaczem i że jego „osobliwa metoda” interpretacji polega na wciąganiu czytelnika „w głąb metapsychologii”, że nadto posługuje się „uwolnion[ą] spod kontroli metaforyk[ą] przekształca[jącą] się w kunszt nazewnictwa rozpalony do temperatury barokowego opisu" (Spytkowski 1961: 264). Jednak szkic Falkowskiego - napisany z polotem i pasją - dowodzi przede wszystkim bardzo dobrej orientacji $\mathrm{w}$ temacie $^{8} \mathrm{i}$ doskonale uzupełnia przekład Hulewicza. I Falkowski, i Hulewicz czytają tragedię Kleista przez pryzmat jego osobistego losu: sztuka ta jest według słów Hulewicza „tematycznie i pozornie, jako pretekst - helleńska, w rzeczywistości jest obrazem przeżyć duchowych samego poety" . Niewykluczone, że i Hulewicz, bezprzykładnie aktywny, a osamotniony i niezrozumiany rozpoznawał w tym dramaturgicznym kostiumie coś osobistego.

Praca nad tłumaczeniem musiała być niezwykle intensywna. W liście do Emila Zegadłowicza z 1 września 1932 roku Hulewicz pisze: „Już pewnie wiesz, że tłumaczę Pentezyleję [sic!] Kleista. Siedzę w drugim akcie, rymowanym 11-zgłoskowcem, a w oryginale jest wiersz biały. Jak sądzisz: który teatr w Polsce mógłby się taką rzeczą poważnie zainteresować...?" (Wielkie rzeczy zrozumienie 2008: 215). Według Mieczysława Urbanowicza przekład był gotowy już w roku 1933 (Urbanowicz 1969: XXII). Przemawia za tym fakt, że finał utworu w opracowaniu teatralnym (recytacje w wykonaniu czwórki aktorów) został zaprezentowany w czerwcu 1933 podczas jednego z cyklicznych spotkań artystycznych zainicjowanych i realizowanych w Wilnie przez Hulewicza w latach 1927-1935 - na 194. Środzie Literackiej. Hulewicz wygłosił słowo wstępne. Odwołując się do aktualnej sytuacji politycznej w Niemczech, miał zapewne w pamięci własne wcześniejsze, zwłaszcza wojenne doświadczenia; wskazywał na literaturę jako ostoję wartości humanistycznych. Wydarzenie odnotował „Kurier Wileński”:

\footnotetext{
${ }^{5}$ Andrea Meyer-Fraatz poświęca w swej książce osobny podrozdział polskiej recepcji Penthesilei Kleista, w tym przekładowi Hulewicza: „Penthesilea” in der Rezeption der polnischen Moderne (Meyer-Fraatz 2002: 208-222). W artykule zasadniczo nie odnoszę się do przeważnie krytycznych uwag A. Meyer-Fraatz o jakości tego przekładu.

6 Pomijając pisownię $z$ „th", forma imienia bohaterki utworu musiała w zamyśle tłumacza brzmieć nie Penthesilea, ale Penthesileia, na co wskazuje rym „dzika zawieja” (wers 14/15).

7 Falkowski wydawał później ten tekst jeszcze kilkakrotnie w czasopismach oraz w zbiorze swoich szkiców literackich Przede wszystkim Sienkiewicz (1959), poświęconych różnym autorom.

8 Falkowski posłużył się przede wszystkim książką Stefana Zweiga o Hölderlinie, Kleiście i Nietzschem, dedykowaną Zygmuntowi Freudowi, a wydaną w roku 1925 Der Kampf mit dem Dämon, stąd też zapewne zapożyczając zarówno tytuł (późniejsze wznowienia posłowia to $W$ asyście demona), jak i niektóre cechy stylu.

9 „Kurier Wileński” z dn. 12 czerwca 1933, omówienie wystąpienia Hulewicza poświęconego Kleistowi, cyt. za: Hernik Spalińska 1998: 198.
} 
Dzisiaj w Niemczech Hitlera, przez wczorajsze Niemcy Bismarcka, sięgamy do najwyższych Niemiec - Goethego. Aby znając ich dzisiejsze oblicze poznać także i tamto, i wytworzyć sobie pełne wyobrażenie o tym narodzie, tak wielki upadek ducha dziś przeżywającym. Postacie w rodzaju Kleista, tak ogólnoludzkie, tak humanitarne, są na tle dzisiejszych Niemiec szczególnie frapujące i zrozumiałe jest zainteresowanie, z którym p. Witold Hulewicz poświęcił się dziełu przyswojenia tego poety literaturze polskiej ${ }^{10}$.

Być może Hulewicz, zajęty przekładem tekstów Rilkego, zainteresował się twórczością Kleista pod wpływem przyjmowanych w Wilnie parę lat wcześniej gości z Niemiec: przede wszystkim znanej z antyfaszystowskich poglądów pisarki i publicystki Elgi Kern. Wygłaszała ona referaty podczas Śród Literackich we wrześniu 1930 i w grudniu 1931 roku, a przy tej okazji także odczyt w wileńskiej rozgłośni Polskiego Radia - o potrzebie kulturalnego zbliżenia niemiecko-polskiego ${ }^{11}$.

Gęsty, kipiący od emocji tekst oryginału, napisany jest blankversem, którego przerzutnie - miejscami karkołomne - wymagają nawet podczas zwykłej lektury dużego skupienia. Wprowadzając w miejsce blankversu jedenastozgłoskowiec kojarzący się z rodzimym romantyzmem i najbardziej wpadający w polskie ucho, Hulewicz z jednej strony dowiódł mistrzowskiego opanowania sztuki przekładu, a z drugiej - naraził się na krytykę: zarzucono mu szereg uchybień i przeinaczeń, jak „niepotrzebny patos”, przekład „zbyt mało zindywidualizowany językowo” i nie w pełni oddający „ekstrawagancję” oryginału (Bartoszewska 1995: 67) ${ }^{12}$.

Krytyka przekładu to dziedzina niemal tak trudna i złożona jak sam przekład, a przy tym głęboko zakorzeniona w subiektywnym osądzie. Hulewiczowi nie można jednak odmówić ani znakomitej kompetencji w obu językach, ani zdolności do refleksji nad tym, jak powstaje i czym przekład literacki być powinien:

[... p ponad dosłowność zewnętrzną (słowo w słowo), ponad ścisłość formalną i wierność filologiczną - stawiam wierność istotną (rzecz w rzecz), ścisłość pojęciową (myśl w myśl) i dosłowność napięcia inspiracyjnego (błysk w błysk), za warunek bezwzględny przyjmując u thumacza bogactwo rzemiosła (Hulewicz 1926: 5-6)

- pisał w obronie przyjaciela Emila Zegadłowicza i jego rzekomo nazbyt swobodnego przekładu Fausta, polemizując z Boyem-Żeleńskim. Identycznymi przesłankami kierował się w pracy nad tekstem Kleista, choć trzeba nadmienić, że również w sferze niezbyt cenionej „dosłowności zewnętrznej” w wielu przypadkach zachował nadzwyczajną wierność wobec oryginału.

10 Cyt. za: Hernik Spalińska 1998: 197-198. W swojej ocenie sytuacji w Niemczech Hulewicz nawiązuje do odczytu Mieczysława R. Frenkla z marca 1933 roku, którego tematem była I wojna światowa i jej skutki (186. Środa Literacka), ibid.: 194.

11 Ibid.: 124-125, 159. Kontakty nawiązane z Elgą Kern wspominano także z okazji jubileuszu pięciolecia Śród Literackich w lutym 1932 roku (ibid.: 164). Według Kalendarium Jagody Hernik Spalińskiej 103. Środa Literacka poprzedzająca wizytę Kernów (Eldze towarzyszył jej mąż Rudolf) i ostatnia przed przerwą wakacyjną były w całości poświęcone twórczości Rilkego: na program złożyły się wprowadzające wystąpienie Hulewicza oraz fragmenty powieści Malte z niepublikowanego jeszcze przekładu oraz wiersze (z Księgi godzin) w wykonaniu samego Stefana Jaracza. W związku z napiętym planem zajęć wybitnego aktora wspomniana Środa Literacka odbyła się w niedzielę 1 czerwca 1930 roku.

12 Zastrzeżenia pod adresem Hulewicza jako tłumacza Rilkego przedstawia także Barbara Surowska, przytaczając również opinie Józefa Wittlina i Juliana Przybosia (Surowska 2017: 146-147). 
W swojej analizie chciałabym skupić się na tytułowej postaci utworu. Nim przejdę do szczegółów, warto pokrótce zarysować dzieje tego dramatu Kleista i sytuację tytułowej bohaterki.

\section{Nieantyczny antyk Kleista: kontrowersje wokół Pentesilei}

Losy królowej Amazonek, która ze swoimi wojowniczymi oddziałami wmieszała się do bitwy pod Troją, to materiał na wskroś antyczny. Jednak Kleist pisze ${ }^{13}$ historię Pentesilei i Achillesa na nowo. Nie chodzi tu tylko o to, że inaczej niż w przekazie najbardziej podówczas rozpowszechnionym ${ }^{14}$ to nie Pentesilea ginie $\mathrm{z}$ ręki Achillesa, lecz on sam zostaje zabity - i z taką wersję zdarzeń poeta mógł zetknąć się w literaturze przedmiotu (Schmidt 1870: 8). Jednak u Kleista makabryczny obrót zdarzeń - Achilles ginie rozerwany na strzępy przez oszalałą z miłości i gniewu królową oraz sforę jej psów - ma w dodatku dwojakie podłoże. Z jednej strony, jak podkreśla jego wybitny biograf Gerhard Schulz, młody autor na długo przed Nietzschem przeczuwa, że prócz jasnej, humanistycznej strony „do antyku przynależy na równi demoniczność barbarzyństwa, chtoniczność” (Schulz 2007: 363). $\mathrm{Z}$ drugiej strony przeczucie to nie wypływa z jego szczególnego zainteresowania kulturą antyczną i studiów nad nią, lecz z własnych doświadczeń i oceny współczesności. Antyczny przekaz służy Kleistowi do własnych eksperymentów i do przeżywania własnych niepokojów (ibid.: 360). Sięgając, zresztą nie po raz pierwszy, po antyczne rekwizyty (walki pod murami Troi, wcześniej także mit o Amfitrionie), nasyca je nowymi treściami, łączy, albo raczej zderza przeciwieństwa. Skutkiem tych zabiegów Pentesilea, protagonistka stworzona przez Kleista, jest spośród bohaterek wszystkich jego utworów postacią „najbardziej nieokiełznaną, brutalną i namiętną a zarazem najbardziej subtelną” (ibid.: 360), natomiast „wojna Amazonek to przede wszystkim wojna płci”, a także walka w imię indywidualności, która z antykiem - zwłaszcza bliskim Goethemu - nie ma wiele wspólnego (ibid.: 363$)^{15}$.

Według Schulza pożegnanie z tradycyjnym, klasycznym wzorcem antyku było zresztą udziałem całego pokolenia młodzieży artystycznej w latach dziewięćdziesiątych XVIII wieku; biograf Kleista przywołuje na poparcie tej tezy poza literatami także malarzy, jak Philipp Otto Runge czy Caspar David Friedrich - twórców szukających inspiracji w chrześcijaństwie (ibid.: 349). Goethe, przywiązany do wizji antyku jako idealnej epoki kwitnącej harmonii i humanizmu, pełniąc przez lata rolę najważniejszego autorytetu na niemieckiej scenie literackiej, doczekał się w końcu sprzeciwu za sprawą młodych niepokornych romantyków, jak Fryderyk Schlegel czy Novalis. Literacką rebelię młodych odczuwał

\footnotetext{
13 Nad sztuką poeta podjął pracę w roku 1805 podczas pobytu w Królewcu, kontynuował ją w niewoli francuskiej, ukończył zaś utwór w Dreźnie w 1807; drukiem wyszły najpierw fragmenty w pierwszym numerze czasopisma „Phöbus", które Kleist wydawał przez krótki czas (styczeń-grudzień 1808) razem z Adamem Müllerem, a jesienią 1808 roku ukazało się wydanie książkowe. Por. Kleist 2008: 933.

14 Oprócz przekazów literackich - chodzi o przedstawienia na zachowanych wazach attyckich i nawiązująca do nich rzeźbę B. Thorvaldsena z 1801 roku pt. Achilles i Pentesilea, która ukazuje Achillesa - zabójcę Pentesilei podtrzymującego (w nagłym przypływie miłości) słaniającą się, umierającą królową.

15 Por. także Skuczyński 2006: 445-454.
} 
jako zagrożenie (ibid.: 350-351), co poniekąd odbiło się na jego stosunku do twórczości Kleista - w szczególności na ocenie Pentesilei; fragmenty utworu przesłał mu Kleist do oceny z najwyższą atencją ${ }^{16}$, ale Goethe miał już okazję wyrobić sobie mało pochlebne zdanie o dramatopisarzu Kleiście na podstawie Amfitriona, sztuki dostarczonej mu - w najlepszej wierze - przez współpracującego z Kleistem Adama Müllera (ibid.: 353). W tragikomedii ${ }^{17}$ tej Zeus, przybrawszy postać wodza Amfitriona, skutecznie konkuruje z nim o względy jego żony Alkmeny. Goethemu już wówczas, w czerwcu 1807 roku, nie przypadł zanadto do gustu sposób obchodzenia się z tematyką antyczną zaproponowany przez młodego autora. Jak to obrazowo przedstawia Schulz, Kleist, wzorem swojej bohaterki Pentesilei, sam nieopatrznie trafil między dwa wrogie obozy jako trudna do zdefiniowania „trzecia siła” i właśnie na nim skupiła się niechęć wszystkich (ibid.: 352). Odpowiedź z Weimaru po lekturze fragmentów nowej sztuki jest szybka (list datowany na 1 lutego 1808 roku) i mimo kilku kurtuazyjnych zwrotów raczej nieprzychylna. Z Pentesileą - bohaterką czy też utworem w ogóle, nie jest to w liście wyrażone jasno - Goethe „nie potrafi się na razie zaprzyjaźnić”, a to przede wszystkim dla jej „przedziwnego pokroju” i niezmiernie „odległych” mu „regionów", w jakich obraca się ta postać (czy też cała sztuka). Sporo czasu wymagałoby dojście z jednym i drugim do ładu (Kleist 2008: 806-807). Udziela też autorowi paru tzw. dobrych rad, których protekcjonalny, a w istocie jadowity ton zdradza irytację ${ }^{18}$.

Nie szczęściło się więc Kleistowskiej Pentesilei w chwili narodzin. Inscenizacja teatralna była możliwa dopiero siedemdziesiąt lat po powstaniu utworu (1876), za to w czasach nam współczesnych dramat ten cieszy się coraz większym, wręcz oszałamiającym powodzeniem scenicznym ${ }^{19}$.

\footnotetext{
16 Por. także list Kleista do Goethego z 24 stycznia 1808 roku (Kleist 2008: 805): „Mam zaszczyt Waszej Ekscelencji przesłać najuniżeniej pierwszy zeszyt »Phöbusa«. Odważam się pojawić z tym przed Panem »klęcząc na kolanach mego serca«; oby uczucie, które onieśmiela mi dłonie, zastąpił[o] wartość tego, co ze sobą przynoszą. Zbyt wielkie żywiłem obawy, by przedłożyć publiczności całość tej tragedii [tzn. Pentesilei - M. K.-Z.], której fragment znajdzie tu Wasza Ekscelencja" (Kleist 1983: 464). W polskim przekładzie listu znalazł się błąd całkowicie wypaczający sens wypowiedzi Kleista: „zastąpiła” zamiast poprawnego „zastąpiło”.

17 Pisząc swoją wersję utworu, Kleist znał także dramat Moliera pod tym samym tytułem.

18 O złożonych przyczynach nieporozumień między Goethem a Kleistem więcej: Schulz 2007: 341-365.

19 Plon ostatnich tylko lat to cały szereg nowych przedstawień: 2011 - Thalia Theater w Hamburgu, 2013/2014 Theater Hof, 2015 - Schauspiel Frankfurt, Theater Augenblicke e.V. w Kilonii i Staatstheater w Darmstadt, 2016/2017 - Theater Schauspielhaus w Chemnitz, 2017 - Theater Duisburg, Zimmer Theater w Tybindze, Pepper Theater w Monachium, 2017/2018 - Konzert Theater w Bernie. Mimo to szczegółowa znajomość tekstu Kleista nadal stanowi wyzwanie nawet dla zawodowych krytyków: Peter Kümmel z renomowanego tygodnika "Die Zeit” sugeruje w swojej recenzji, niezgodnie z treścią sztuki, że Amazonki brutalnie mordują "dawców nasienia" po spełnieniu przez nich tej funkcji („Die Amazonen brauchen keine Männer, sie brauchen bloß Samenspender, die sie nach vollzogenem Akt massakrieren", P. Kümmel, Der Zahn im Schlund des anderen. Triumph der Rhetorik: Michael Thalheimer inszeniert Kleists „Penthesilea" am Schauspiel Frankfurt, 4. Januar 2016, http://www.zeit.de/2015/50/ theater-michael-thalheimer-kleist-penthesilea [26.05.2017]). Należy odnotować także polską prapremierę sztuki zrealizowaną w ramach polsko-niemieckiego projektu teatralnego przez Künstlerhaus Bethanien, Podewil oraz PWST w Krakowie. SpektakI (na podstawie przekładu Jacka S. Burasa) był prezentowany w Krakowie i Berlinie w roku 1995.
} 


\section{Fascynujący brak umiaru}

Nie musiała jednak Pentesilea czekać na wielbicieli aż tak długo. Już klimat pierwszych dziesięcioleci XX wieku okazał się dla niej łaskawy, co więcej: wierni miłośnicy zafascynowani „wpół Furią, na wpół Gracją” (Kleist 1969: 139) wywodzili się z zupełnie różnych środowisk. Ekspresjoniści Ernst Stadler czy Oskar Kokoschka ${ }^{20}$ nie dziwią w tym gronie. Ale o dramacie Kleista wręcz ciepło wypowiada się w jednym z listów ${ }^{21}$ do Romana Ingardena zaprzyjaźniona z nim Edyta Stein. Krótka wiadomość pochodzi z września 1918 roku. Chaos wojenny nie sprzyja ciągłości korespondencji, część listów nie dociera do adresata. Ten los spotyka też jedną z przesyłek książkowych: „zaginioną książkę przeznaczyłam dla Pana”, wyjaśnia Edyta Stein,

by wyrwać Go ze smutnego nastroju, widocznego wówczas w Pańskich listach. Była to Penthesilea Kleista; bardzo ją lubię, a i Panu podobała się, gdy dałam ją Panu przeczytać przed dwoma laty. Było to takie ladne wydanie oficyny Tempel i nic dziwnego, jeśli po drodze znalazło amatora. Księgarzowi chyba poczta wypłaci odszkodowanie, a Panu postaram się to wynagrodzić, kiedy przyjedzie Pan do Niemiec ${ }^{22}$.

Zaskakiwać może tu zarówno pogodny ton („bardzo ją lubię”), jak i uwaga, że akurat historią z tak krwawym finałem można poprawić sobie czy komuś nastrój. Co więcej, po lekturę tę sięga się tu wielokrotnie, dla czystej czytelniczej przyjemności.

Najwyraźniej ta sama cecha sztuki, która przesądziła niegdyś o jej odrzuceniu, z czasem staje się jej cennym walorem. Jest to tekst pełen szaleńczego wprost napięcia. „Szaleństwo” to Kleist tłumaczył jako odbicie prawdy o nim samym. W liście do swej powierniczki i mentorki Marii von Kleist, z którą mimo zbieżności nazwisk łączyło go jedynie pokrewieństwo dusz, wyznaje: „Nieopisanie mnie wzrusza wszystko, co Pani mi pisze o Penthesilei. To prawda, w niej cała ma najskrytsza istota, i Pani to niczym jakaś jasnowidząca odgadła: w niej wszystek ból i zarazem cały blask mojej duszy” (Kleist 1983: 454) ${ }^{23}$. Przeczuwana i domniemana tu „prawda istnienia” ${ }^{24}$ oczarowuje dwudziestowiecznych czytelników dramatu ze szkoły Husserla.

W latach trzydziestych XX wieku filmowa adaptacja dramatu i wcielenie się w tytułową rolę stały się (niespełnionym) marzeniem Leni Riefenstahl, która już w roku 1933, zaraz po ukończeniu filmu Zwycięstwo wiary o zjeździe NSDAP w Norymberdze, zapaliła się do tego projektu, następnie wróciła do swego pomysłu w roku 1939, również bez powodzenia,

\footnotetext{
20 Stadler wskazywał już w 1909 roku na pokrewieństwo pojmowania antyku przez Kleista i Nietzschego, a Kokoschka czerpał z dramatu Kleista inspirację do własnej sztuki Morderca, nadzieja kobiet z roku 1907. Por. Essen 2009: 115. Na uwagę zasługują także pojawiające się w pierwszych dziesięcioleciach XX wieku ekskluzywne wydania tragedii, jak edycja monachijska z 1917 roku, bogato ilustrowana litografiami Richarda Seewalda, czy wydanie w dużym formacie, liczące aż 146 stron z roku 1923 (Stuttgart).

21 O korespondencji Edyty Stein z Ingardenem por. Klentak-Zabłocka 2006: 225-237 oraz Klentak-Zabłocka 2011: 155-162.

22 Kartka pocztowa z 28 września 1918 roku (nr 49), św. Teresa Benedykta od Krzyża. Edyta Stein 2003: 147.

23 Osobnym zagadnieniem jest dyskusja nad prawomocnością użycia w przytoczonym fragmencie listu słowa "ból": oryginał zaginął, tekst znany jest tylko w odpisie adresatki listu, w którym w tym miejscu napisane jest nie słowo „Schmerz" (ból), lecz, Schmutz" (brud); por. Schulz 2007: 567.

24 Spóro prawdę istnienia to jednocześnie tytuł pierwszego polskiego wydania listów Edyty Stein do Ingardena, (Stein 1994).
} 
mimo że specjalnie w tym celu powołała do życia przedsiębiorstwo „Leni Riefenstahl Film GmbH” (http://archive.li/UEkFi [6.06.2017]). Ostatecznie uniemożliwił realizację filmu wybuch wojny. W godzinnym wywiadzie ${ }^{25}$ zarejestrowanym przez Sandrę Maischberger w roku 2002 stuletnia Riefenstahl dokładnie pamięta, że na jej widok Max Reinhardt wykrzyknął kiedyś z zachwytem: „Nareszcie znalazłem moją Pentesilę̨!”. Zarówno indywidualno-psychologiczna konstrukcja tytułowej bohaterki, jak i estetyczna wizja inscenizacji całego utworu nadzwyczajnie pociągały ją także jako wyzwanie zawodowe. „Maßlosigkeit”26 Pentesilei i Kleista, ów brak umiaru i bezmiar namiętności działały z magnetyczną siłą, fascynowała i imponowała też samobójcza śmierć bohaterki, dokonana samą tylko siłą woli ${ }^{27}$, a styl Kleista porywał i usidlał.

W tym samym czasie, gdy Leni Riefenstahl marzyła o przetłumaczeniu Kleista na język filmowych obrazów, Witold Hulewicz podjął pracę nad polskim przekładem dramatu.

\section{Postać Pentesilei u Kleista i u Hulewicza}

Wróćmy do losów samej Pentesilei. Na czele swoich wojsk królowa sieje popłoch pod Troją: Amazonki nie wspierają żadnej ze stron, lecz walczą z każdym mężczyzną. Nakazuje im to odwieczne prawo: zwyciężyć na polu bitwy przeciwników wskazanych przez Marsa. Tym razem bóg wojny nakazał im ustami kapłanki udać się pod Troję i zabrać jeńców do siedziby w Temiscyrze, skąd, odprawiwszy prokreacyjne misterium Święta Róż, hojnie obdarowanych puszcza się ich wolno. Amazonce nie godzi się kierować na polu bitwy własnym wyborem. Wbrew temu obyczajowi Pentesilea wyruszyła na wojnę z zamiarem pokonania Achillesa, ponieważ matka zdradziła jej na łożu śmierci, że takie jest jej przeznaczenie. Od samego początku wiąże ją więc posłuszeństwo wobec dwu sprzecznych praw: z jednej strony jest to „ogólne” prawo Amazonek, z drugiej - „szczególne” proroctwo-polecenie umierającej. Na polu bitwy pod Troją nieoczekiwanie opanowuje ją trzecia i najpotężniejsza siła: jak grom z jasnego nieba poraża młodą królową namiętna miłość, gdy staje z Achillesem twarzą $\mathrm{w}$ twarz ${ }^{28}$. Odtąd Pentesilea, całkowicie osamotniona, bo niezrozumiana przez nikogo, dąży do zwycięstwa za wszelką cenę, budząc to podziw, to zgrozę. Sztuka składa się z 24 scen, a motywacje bohaterki odkrywa Kleist dopiero w lirycznej scenie 15, gdy Pentesilea jest przekonana, że pokonała Achillesa w walce. W rzeczywistości w pojedynku ranił i pokonał ją Achilles, ale w chwili, gdy zdaje mu się, że ją zabił - Pentesilea traci przytomność -

\footnotetext{
25 Informację o filmie The Immoderation of Me zawdzięczam Marii Gierlak.

${ }^{26}$ W wersji niemieckiej tytuł brzmi Die Maßlosigkeit, die in mir ist i wyraźniej nawiązuje do fascynacji postacią Pentesilei.

27 Janusz Skuczyński, stwierdzając że Pentesilea przebija się w końcu sztyletem (Skuczyński 2006: 453), nie jest precyzyjny, bo choć w jej ostatnim monologu o sztylecie mowa: II kuję, ostrzę sobie sztylet [...] / I sztyletowi teraz pierś podaję: / Tak! Tak! Tak! Tak! I jeszcze!”, to materiałem, z którego „uczyniono” ów zabójczy sztylet, jest „jak zimny spiż / zagłady myśl” - a zatem sama tylko wola bohaterki (Kleist 1969: 176-177).

${ }^{28}$ W relacji Odyseusza: „Wtem oko jej spotyka wzrok Achilla - / I niby pożar z czerwonych płomieni / Nagły rumieniec jej lica odmieni, / Ciemną purpurą biel twarzy nasila. / Skacze na ziemię (koń przysiadł na zadzie), / Przez jedną chwilę stoi w ziemię wryta; / Cugle ciskając służebnej zapyta: / Co nas prowadzi w tak wielkiej paradzie?" (Kleist 1969: 5); scenę „rozpoznania” - nieczytelnego dla postronnych - powtórzy potem Kleist w Kasiz Heilbronn, o której to pisał zresztą, że jest ona „przeciwieństwem” Pentesilei: „to jej drugi biegun, istota, co równie jest potężna dzięki swemu bezgranicznemu oddaniu jak tamta dzięki swemu działaniu" (Kleist 1983: 454).
} 
i w nim wybucha miłość. Wówczas Protoe, najwierniejsza podkomendna Pentesilei, nakłania Achillesa, by ukryć przed królową - gdy się ocknie - prawdę i w ten sposób chronić ranną władczynię przed szokiem, który z pewnością byłby dla niej zabójczy. Kiedy jednak w końcu faktyczny stan rzeczy wychodzi na jaw, nic nie jest w stanie ukoić bólu Pentesilei z powodu doznanego upokorzenia. Wprawdzie zostaje ponownie uwolniona przez dzielne towarzyszki, ale sprzeczne uczucia doprowadzają ją do obłędu. Gdy zakochany Achilles pozoruje kolejny pojedynek i zbliża się bez broni, aby uczynić zadość pragnieniom królowej i naprawdę zostać jej jeńcem, Pentesilea jest już tylko Furią, ślepą na subtelną grę pozorów. Razem ze sforą psów rozrywa ukochanego na strzępy, po czym - odzyskawszy rozeznanie własnych czynów - zadaje sobie śmierć, siłą samej tylko woli.

Polska wersja tragedii na równi z oryginałem oddaje waleczność, fizyczną zręczność i urodę dwudziestotrzyletniej Amazonki. Z racji specyfiki utworu, na który - poza masakrą w finale - składają się liczne sceny bitewne, niemożliwe do pokazania na scenie, Kleist bardzo często stosuje tu teichoskopię. Znamienne jest więc dla tej sztuki wielkie nagromadzenie peryfraz, służących zarówno opisowi działań podejmowanych przez Pentesileę, jak i ich natychmiastowej ocenie przez inne postacie dramatu. Przy tym, stosownie do skomplikowanego przebiegu zdarzeń i zmiennej perspektywy, ogromna jest rozpiętość emocjonalna kilkudziesięciu określeń i tytułów protagonistki (niektóre występują wielokrotnie). Raz są to takie wyrażenia, jak: „Sturmwind” / „dzika zawieja”, „die Kentaurin” / „centaurzyca”, „die Hyäne, die blind-wütende” / „hiena obłędna i ślepa”, „die Sinnberaubte” / „jak z rozumu obrana”, „die rasende Megär” / „wściekła Megera”, „Entsetzliche” / „straszna”, „die Sinnberaubte” / „oszalała”, „die Rasende” / „szalona”; innym razem - „die Göttliche” / „boska dziewa”, „Überwinderin” / „zwycięska pani”, „Herrscherin” / „władczyni, pani”, „Königin, Fürstin” / „królowa, monarchini”, ale i - „Träumerin” / „marzycielka”, „Geliebte” / „ukochana, najdroższa”, „Braut” / „oblubienica”, „mein süßes Herz” / „słodkie serce”, „mein Schwesterherz, mein süßes, o mein Leben” / „serce siostrzane, słodkie, moje życie” - a w końcu - „Unselige” / „nieszczęsna”, „die Verlorenste der Frauen” / „z kobiet najstraszniej zgubiona”, „Hündin” / „suka”, „die Grauenvolle” / „upiorna”, „die Gräßliche, [ ... ] Scheußliche” / „w całej ohydzie wyniosła i sroga”, „Unglückliche” / „nieszczęśliwa”, „die Ungeheuerste” / „najstraszliwsza”. W obu wersjach językowych Pentesilea jawi się więc jako postać charakterologicznie niezwykle dynamiczna, nieprzewidywalna i nieobliczalna.

Zewnętrznie jest to jednak młoda, piękna kobieta. Czytelnik zapamięta jej gibkość, zwinność i szybkość, pałające spojrzenie, bujne włosy - loki wysypujące się spod hełmu. Co ciekawe, w przekładzie Hulewicz nazywa Pentesilę „złotowłosą”, mówi też o „złotych włosach” i o „kędziorach złotej głowy”, podczas gdy u Kleista są to tylko „Locken” / [loki, pukle $]^{29} \mathrm{i}$ „seidene Haare” / „jedwabne kędziory”. Dzięki tej modyfikacji w postaci królowej Amazonek jeszcze wyraźniej ujawnia się podobieństwo do przeznaczonego jej przez los przeciwnika i ukochanego - Achillesa, którego musiałaby najpierw pokonać w bitwie, by móc oddać mu się w miłości. W następujących fragmentach oryginału (Kleist 2008: 355-356) i przekładu (Kleist 1969: 53-54) widać, że Hulewicz dodał do postaci Pentesilei nieobecny w tym miejscu w tekście niemieckim efekt świetlistości, charakteryzujący Achillesa („złote włosy” - powiązana z Pentesileą cecha - pojawia się trzykrotnie w innych miejscach i dopełnia tego obrazu). Tym sposobem w przekładzie dobitniej przemawia do czytelnika

29 W nawiasach kwadratowych podaję własne tłumaczenia, nie zawsze pokrywające się z wersją Hulewicza. 
„kompatybilność” obu postaci. Mamy tu do czynienia z amplifikacją, zgodną jednak z duchem utworu, ponieważ Pentesilea i Achilles są do siebie także w zamyśle Kleista bardzo podobni pod względem osobowości. Przytaczam tu dość obszerny cytat dla lepszego zilustrowania stopnia trudności zadania translacyjnego i poetyckiego kunsztu tłumacza (wyróżnienia moje - M. K.-Z).

\section{DIE HAUPTMÄNNIN.}

Zum Kampf steht sie gerüstet, Ich sag's euch, dem Peliden gegenüber, Die Königinn, frisch, wie das Perserroß, Das in die Luft hoch aufgebäumt sie trägt, Den Wimpern heiß're Blick', als je, entsendend, Mit Athemzügen, freien, jauchzenden, Als ob ihr junger kriegerischer Busen Jetzt in die erste Luft der Schlachten käme. $[\ldots]$

\section{DAS ERSTE MÄDCHEN}

Seht, seht, wie durch der Wetterwolken Riß, Mit einer Maße Licht, die Sonne eben

Auf des Peliden Scheitel niederfällt!

\section{DIE OBERPRIESTERINN}

Auf wessen?

\section{DAS ERSTE MÄDCHEN}

Seine, sagt' ich! Wessen sonst? Auf einem Hügel l e u c h t e n d steht er da, In Stahl geschient sein Roß und er, d e r S a p h i r, Der Chrysolith, wirft solche Strahlen nicht!

Die Erde rings, die bunte, blühende, In Schwärze der Gewitternacht gehüllt; Nichts als ein dunkler Grund nur, eine Folie, Die Funkelpracht des Einzigen zu heben!

\author{
NACZELNICZKA \\ Do boju gotowa, \\ Na wprost Pelidy, drwiąca z jego strzałów, \\ Stoi królowa, świeża jak jej perski \\ Rumak wysoko wspięty, a jej głowa \\ Skrzy się jaknigdy, taki z niej rycerski \\ $\mathrm{Bl}$ a sk bucha, ża r i taka radość nowa, \\ Jak gdyby młoda jej pierś marmurowa \\ Pierwszy raz w życiu wdychała dech wojny. \\ $[\ldots]$
}

\section{PIERWSZE DZIEWCZE}

Patrzcie, przez chmury rozcięte

Runęło słońce: snopy światła biją

Prosto na Pelidy skroń!

\section{ARCYKAPEANKA \\ Na czyją?}

\section{PIERWSZE DZIEWCZE}

Na jego skroń. O, patrzcie, siostry, w dal: Ś w i e c ą cy stoi na wzgórzu i w stal Zakuty, on i rumak - od s z a fir u I chryzolitu skrzy się promienniejszy! Ziemia dokoła zasnuta w cień kiru Gromowej nocy, podkład najczarniejszy Jednemu daje - i b l a s k i swe traci, By oddać przepych tej jednej postaci.

Innego rodzaju odstępstwo od oryginału pojawia się natomiast $\mathrm{w}$ scenie $\mathrm{V}$, w wersie 720, kończącym monolog Pentesilei. W monologu tym królowa Amazonek stara się przekonać wierną Protoe (i siebie samą), że jej pragnienie zwycięstwa nad Achillesem nie wypływa z osobistych pobudek, lecz przeciwnie: z troski o społeczność i dobro całego ludu. W ten sposób Pentesilea usiłuje pogodzić sprzeczności: chce bowiem zdobyć Achillesa dla siebie, ale podjęcie związanego z tym ryzyka usprawiedliwia rzekomym interesem grupowym; na koniec rzuca znamienne zdanie: „Verflucht das Herz, das sich nicht mäß'gen kann” [Przekleństwo sercu, co nie zna umiaru]. Co mają znaczyć te słowa w takim kontekście? Protoe ich nie rozumie, ale ma złe przeczucia - „so finster, wie der ewigen Nacht entstiegen” [tak mroczne, jak zrodzone z wiecznej nocy]: „Twe oko, pani, zgoła obco płonie, / 
/ Niezrozumiale - i w dziwnej rozterce / Ciemne się tłuką przeczucia w mym łonie...” (Kleist 1969: 38).

Można by przyjąć, że wypowiadając zdanie o „przeklętym sercu”, Pentesilea chce podkreślić bezinteresowność swego postępowania: przeklęty byłby ten, kto nie umie spraw ogółu przedłożyć nad własne; przeklęty, kto nie może poskromić swego serca, ale (domyślnie) ona potrafi tego dokonać. Można jednak pójść innym tropem, tym mianowicie, że Pentesilea wypowiada mimowolnie, niejako wbrew sobie i przeciwko sobie, w tonie skrytego samooskarżenia zdanie iście prorocze. Jej serce naprawdę „nie zna umiaru”. W głębi duszy królowa wie, że nie wolno jej podporządkowywać spraw państwa i całej wojny jedynie prywatnej namiętności, a jednak to właśnie uczyni. Zdanie kończące monolog wyrażałoby wówczas przeczucie własnej zguby z powodu braku umiaru. Nigdzie indziej Pentesilea nie mówi w ten sposób. Tymczasem w przekładzie Hulewicza ta sama kwestia brzmi: „Kto waha się, ma podłe serce!”30, co na pierwszy rzut oka jest sprzeczne z oryginałem. Co skłoniło tłumacza do przyjęcia takiego rozwiązania? Czy to tylko przeoczenie, czy klucz tkwi w zawierającym się w czasowniku „sich mäßigen”31 słowie „Maß” (miara)? Jeżeli „sich mäßigen” rozumieć jako „być wiernym »mierze«”, a sercem miałaby kierować „miara”, tzn. pewna i jasno ustalona wytyczna, wówczas rzeczywiście za przeciwieństwo takiego stanu można by uznać nie tylko brak „miary” w sensie braku umiaru, ale i brak konsekwencji, chwiejność i wahanie, co doprowadza nas do rozwiązania przyjętego przez Hulewicza, dość odległego od wersji narzucającej się w pierwszym odruchu. Jest to wprawdzie kręta droga rozumowania, ale za taką interpretacją przemawiałaby osobista postawa Witolda Hulewicza: człowieka do końca wiernego własnym przekonaniom. Nie należy wykluczać wpływu czynników natury nawet bardzo osobistej na efekt pracy tłumacza poezji.

Translatorskie dokonanie Witolda Hulewicza w postaci tłumaczenia Pentesilei jest dziełem poruszającym także $\mathrm{z}$ tego powodu, że stanowi jedynie fragment twórczej aktywności tego wszechstronnego autora. Jest to ocalała cząstka, budząca refleksję o stratach bezpowrotnych, takich choćby, jak gotowa do druku książka Hulewicza o Chopinie ${ }^{32}$, której rękopis najprawdopodobniej spłonął w Warszawie. Powojenne wydanie Pentesilei w serii Biblioteki Narodowej Ossolineum, prócz odnotowanego nazwiska tłumacza, nie zawiera żadnych informacji o jego warsztacie, o okolicznościach powstania przekładu ani o losach tak przekładu, jak i jego twórcy.

Tymczasem Hulewicz, niestrudzony propagator kultury niemieckiej w Polsce, niemal dokładnie osiem lat po wileńskim spotkaniu poświęconym Kleistowi i Pentesilei, kiedy to wzywał do poznawania poprzez literaturę niemieckiej duszy, by mieć „pełne wyobrażenie o tym narodzie”, zginął z rąk tych, którzy wówczas naród ten reprezentowali. Został rozstrzelany w Palmirach 12 czerwca 1941 roku: „Przed hitlerowskim plutonem egzekucyjnym

\footnotetext{
30 Nieco inna wersja, bardziej jeszcze odbiegająca od tekstu Kleista - wręcz zaprzeczenie oryginału - widnieje jako motto w polskim wydaniu listów poety: „Przekleństwo sercu, które szuka umiaru ...” (Kleist, 1983: 5), bez podania nazwiska tłumacza; por. także Klentak-Zabłocka 2013.

31 Co ciekawe, Kleist dokonał w tym miejscu korekty w rękopisie swego dramatu z "bändigen” („ujarzmić”, „okiełznać") na łagodniejsze „mäßigen". Ślad tej i innych korekt poety zachowano w jednej z edycji dramatu z roku 1921, wydanej we Frankfurcie nad Menem, opracowanej na podstawie rękopisu Kleista przechowywanego w Preußische Staatsbibliothek w Berlinie.

32 Hulewicz chciał napisać biograficzny cykl o wybitnych osobowościach artystycznych; w roku 1927 opublikował jedynie swoją poruszającą opowieść Przybłęda Boży. Beethoven. Czyn i człowiek, a także niespełna trzydziestostronicową broszurę Stanisław Moniuszko. Król pieśni polskiej (Lwów 1933).
} 
dopełniły się dni subtelnego tłumacza literatury, osobistego przyjaciela Rilkego, wybitnego pisarza i twórcy radiowego Teatru Wyobraźni” (Kwiatkowski 1971: 7). Podczas ekshumacji przeprowadzonej w roku 1946 zwłoki Witolda Hulewicza udało się zidentyfikować m.in. na podstawie medalika z podobizną Matki Boskiej Ostrobramskiej oraz zapalniczki, kupionej w Berlinie podczas Olimpiady, którą Hulewicz relacjonował dla Polskiego Radia (ibid.).

\section{Bibliografia}

Bartoszewska, Irena 1995. Witold Hulewicz. Ttumacz i propagator literatury niemieckiej w Polsce. Łódź: Wydawnictwo Uniwersytetu Łódzkiego.

Essen, Gesa von 2009. Die Resonanzen Nietzsches im Drama des expressionistischen Jahrzehnts. https://www.klassik-stiftung.de/uploads/tx_lombkswdigitaldocs/Nietzsche_2009_von_ Essen.pdf [5.06.2017].

Hernik Spalińska, Jagoda 1998. Wileńskie Środy Literackie (1927-1939). Warszawa: Wydawnictwo IBL PAN.

Hulewicz, Witold 1926. Polski Faust. Rzecz o nowych polskich przekładach, o sposobach ttumaczenia i polemice dookolnej. Warszawa: Skład Główny w „Domu Książki Polskiej”.

Hulewicz-Feillowa, Agnieszka 1988. Rodem z Kościanek. Kraków: Wydawnictwo Literackie.

Karaś, Agnieszka 2003. Miał zbudować wieżę. Życie Witolda Hulewicza. Warszawa: Oficyna Literatów i Dziennikarzy POD WIATR.

Kleist, Henryk [Heinrich von] 1938. Penthesileia: tragedia. Tłum. Witold Hulewicz. Lwów: Nakładem Filomaty.

- 1969. „Pentesilea”. W: Henryk Kleist. Dramaty i nowele. Tłum. Witold Hulewicz, Jan Sztaudynger, Edyta Sicińska. Wstęp i komentarz Mieczysław Urbanowicz. Wrocław-Warszawa-Kraków: Zakład Narodowy im. Ossolińskich - Wydawnictwo.

- 1983. Listy. Przekład i wstęp Wandy Markowskiej. Warszawa: Czytelnik.

- 2008. Sämtliche Werke und Briefe. Hrsg. H. Sembdner. Zweibändige Ausgabe in einem Band. München: Deutscher Taschenbuchverlag.

Klentak-Zabłocka, Małgorzata 2006. „Edith Steins Briefe an Roman Ingarden”. W: Marion Brandt (hrsg.). Grenzüberschreitungen. Deutsche, Polen und Juden zwischen den Kulturen (1918-1939). Colloquia Baltica Nr 6: Beiträge zur Kultur und Geschichte Ostmitteleuropas. München: Martin Meidenbauer Verlagsbuchhandlung.

— 2011. „Edyta Stein a Polska. Listy do Romana Ingardena z lat 1917-1918”. W: Ewa Graczyk, Monika Graban-Pomirska, Karolina Cierzan, Paulina Biczkowska (red.). Dwudziestolecie mniej znane. O kobietach piszacych w latach 1918-1939. Z antologia. Kraków: LIBRON.

- 2013. „Zwischen Fremdheit und Vertrautheit. Heinrich von Kleist in der neueren polnischen Literatur". Komparatistik. Jahrbuch der Deutschen Gesellschaft für Allgemeine und Vergleichende Literaturwissenschaft 2012: 73-85.

Kümmel, Peter 2016. Der Zahn im Schlund des anderen. Triumph der Rhetorik: Michael Thalheimer inszeniert Kleists 'Penthesilea' am Schauspiel Frankfurt. (4. Januar 2016). http://www.zeit. de/2015/50/theater-michael-thalheimer-kleist-penthesilea [26.05.2017].

Kwiatkowski, Maciej 1971. „To przecie człowiek był ...”. Radio i Telewizja 25: 7-9.

Meyer-Fraatz, Andrea 2002. Die slavische [sic! - M. K.-Z.] Moderne und Heinrich von Kleist. Zur zeitbedingten Rezeption eines Unzeitgemäßen in Rußland, Polen und Kroatien. Wiesbaden: Harrassowitz Verlag. 
Schmidt, Erich 1870. [Wstęp]. W: H. v. Kleists Werke. Im Verein mit Georg Minde-Pouet u. Reinhold Steig hrsg. v. Erich Schmidt. Leipzig: Bibliographisches Institut.

Schulz, Gerhard 2007. Kleist. Eine Biographie. München: Verlag C. H. Beck.

Skuczyński, Janusz 2006. „Ifigenia i ‘Anty-Ifigenia’ Goethego i Kleista”. W: Maria Kalinowska, Ewa Owczarz, Janusz Skuczyński, Marcin Wołk (red.). Prace z historii i teorii literatury ofiarowane Profesorowi Jerzemu Speinie. Toruń: Wydawnictwo Uniwersytetu Mikołaja Kopernika.

Spytkowski, Józef 1961. „Przede wszystkim Sienkiewicz”. Pamiętnik Literacki 52/3: 259-266.

Stein, Edith 1994. Spór o prawdę istnienia. Listy Edith Stein do Romana Ingardena. Tłum. Małgorzata Klentak-Zabłocka, Andrzej Wajs. Kraków: Wydawnictwo m.

Surowska, Barbara 2017. „'Tlumaczenie to jest wielka rzecz...' Rainer Maria Rilke w przekładach polskich". W: Barbara Surowska. Od Goethego do Grassa. Szkice z literatury niemieckiej. Warszawa: Instytut Germanistyki Uniwersytetu Warszawskiego.

Surynt, Izabela 2017. „Witold Hulewicz (1895-1941). Zwischen Kulturen und Nationen”. W: Krzysztof Ruchniewicz, Marek Zybura (hrsg.). „Der du mein ferner Bruder bist ... ” Polnische Deutschlandfreunde in Porträts. Studia Brandtiana 7. Osnabrück: fibre Verlag.

św. Teresa Benedykta od Krzyża, Edyta Stein 2003. Autoportret z listów, cz. III, Listy do Romana Ingardena. Wprowadzenie Hanna Barbara Gerl-Falkowitz. Oprac. i przypisy Maria Amata Neyer OCD. Wspólpraca Eberhard Avé-Lallemant. Tłum. Małgorzata Klentak-Zabłocka (wprowadzenie, listy 1-64), Andrzej Wajs (listy 65-163). Kraków: Wydawnictwo Karmelitów Bosych.

Urbanowicz, Mieczysław 1969. [Wstęp]. W: Henryk Kleist. Dramaty i nowele. Thum. Witold Hulewicz, Jan Sztaudynger, Edyta Sicińska. Wstęp i komentarz Mieczysław Urbanowicz. Wrocław-Warszawa-Kraków: Zakład Narodowy im. Ossolińskich - Wydawnictwo.

Wielkie rzeczy zrozumienie. Korespondencja Jerzego, Witolda $i$ Wandy Hulewiczów z Emilem Zegadtowiczem (1918-1938) 2008. Opracowal i wstępem opatrzył Mirosław Wójcik. Warszawa: Państwowy Instytut Wydawniczy. 